Nevşehir Bilim ve Teknoloji Dergisi (2019), 8(Enar Özel Sayı) 1-19

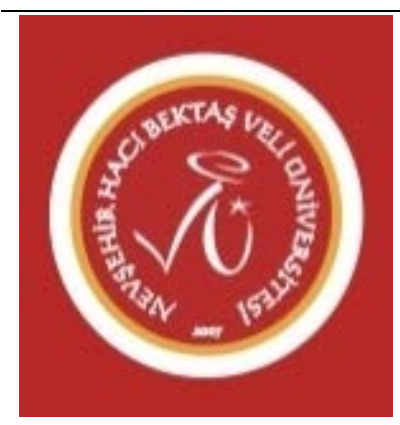

Nevşehir Bilim ve Teknoloji Dergisi

dergi web sayfası: http://dergipark.gov.tr/nevbiltek

Makale Doi: 10.17100/nevbiltek.568395

Geliş tarihi: 21.05.2019 Kabul tarihi: 02.09.2019

\title{
Avrupa Yeşil Başkentlerin Yeşil Alan Politikalarının İncelenmesi
}

\author{
M. Akif IRMAK ${ }^{1}$, Büşra AVCI ${ }^{1}$ \\ ${ }^{1}$ Atatürk Üniversitesi, Mimarlık ve Tasarım Fakültesi, Peyzaj Mimarlı̆̆ı Bölümü, Erzurum \\ ORCID ID:0000-0001-8285-5341 \\ ORCID ID:0000-0003-1108-808X
}

Öz

Birleşmiş Milletlerin 2018 y1lı Dünya Şehirleşme Raporlarına göre dünya nüfusunun \%55.3’ü kentlerde yaşamaktadır. Dünya genelinde kentlerde yaşayan nüfus oranı 1950'li yıllarda \%30 civarında iken, 2030 yılına kadar \% 60'a ulaşması beklenmektedir. Hızla artmakta olan kentleşme eğilimi nedeniyle, kentsel alanlarda hayati öneme sahip olan açık ve yeşil alanların varlığı, büyüklüğü ve etkin kullanımı gibi kavramlar oldukça önem kazanmıştır. Açık ve yeşil alanlar; kentsel ve kırsal alanlar arasında bağlantı kurma, rekreasyonel aktiviteler için olanak sağlama, çevre kirleticilerinin etkisini azaltma, mikroklimayı ve yüzey akışlarını düzenleme, kent estetiğini iyileştirme, bitki ve yaban hayatı türleri için uygun yaşam alanı oluşturma, insanların yaşam koşullarını iyileştirme ve daha birçok işlevi yerine getiren önemli kentsel biyotoplardır.

Bu çalışma kapsamında, yeşil başkent kavramı ve Avrupa Yeşil Başkentleri üzerinden açık ve yeşil alanlara yönelik politikalarının incelenmesi amaçlanmıştır. Hayatın olağan akışı içerisinde fazlaca öneme sahip olan açık ve yeşil alanlar için kentsel yaşam kalitesini vurgulayan ve çevreci yönüyle dikkat çeken "yeşil başkent" kavramı ve bu kapsamda uluslararası tanınırlı̆̆ı olan "yeşil başkent ödülü” irdelenmiş̧ir. Bu ödülü kazanan kentlerin Türkiye'de yeterince tanınmadığı ve bu konuda Türkiye'de az sayıda araştırma yapıldığı gözlemlenmiştir. Bu amaç doğrultusunda, 20102020 yılları arasında Avrupa Yeşil Başkenti seçilen Stolkholm, Hamburg, Vitoria-Gasteiz, Nantes, Kopenhag, Bristol, Ljubljana, Essen, Nijmegen, Oslo ve Lizbon kentleri incelenmiştir. Çalışmada literatür ve belge tarama yöntemi kullanılmış olup, Yeşil Başkent ünvanına sahip olabilmek için gerekli olan 12 gösterge çerçevesinde konu değerlendirilmiştir. Hazırlanan Yeşil Başkent başvuru raporlarında bulunan "Yerel Ulaşım ve Sürdürülebilir Arazi Kullanımını İçeren Yeşil Kentsel Alanlar” başlıklı bölümler üzerinde yoğunlaşılmıştır. Yapılan incelemeler sonucunda Türkiyenin yeşil alanlarına ilişkin temel politikaları değerlendirilmiştir. Ayrıca Türkiye'den yeşil başkent ödülü için aday gösterilen kentlerin açık ve yeşil alanlara yönelik uygulamaları tartışılmıştır.

Anahtar Kelimeler: Yeşil Başkentler, Avrupa Yeşil Başkentleri, Açık ve Yeşil Alanlar, Yeşil Alan Politikaları.

\section{Investigation of Green Area Policies of European Green Capitals}

\section{Abstract}

Acording to the 2018 World Urbanization Report of the United Nations, 55.3\% of the world's population lives in urban areas. The proportion of the population living in cities across the world is expected to reach $60 \%$ by 2030 while it is around $30 \%$ in the 1950s. Due to the rapidly increasing urbanization trend, concepts such as the presence, size and effective use of open and green areas, which are vital in urban areas, have gained importance. Open and green areas; linking between urban and rural areas, providing opportunities for recreational activities, reducing the impact of environmental pollutants, regulating microclimate and surface flow, improving urban aesthetics, creating a suitable living space for plant and wildlife species, improving people's living conditions and performing many other functions important urban biotopes. 


\section{Nevşehir Bilim ve Teknoloji Dergisi (2019), 8(Enar Özel Sayı) 1-19}

The aim of this study is to examine the policies of open and green areas through Green Capital concept and European Green Capitals. The concept of green capital which emphasizes the quality of urban life and draws attention with its environmentalist approach and in this context the international recognition of green capital award are discussed for the open and green areas which have much importance in the normal course of life. This award winning of cities, far enough not recognized in Turkey, and it was observed that a small number of research in Turkey on this issue. For this purpose, Stolkholm, Hamburg, Vitoria-Gasteiz, Nantes, Kopenhag, Bristol, Ljubljana, Essen, Nijmegen, Oslo and Lizbon cities which were selected as European Green Capital between 2010-2020 were examined. In the study, literature and document scanning method has been used and the subject is evaluated within the frame of 12 indicators which are required to have the title of Green Capital. In the Green Capital prepared application reports, it is focused on the sections titled 'Local Transport and Green Urban Areas Incorporating Sustainable Land Use'. Turkey's basic policies on green areas as a result of the examinations were evaluated. In addition, applications for open and green areas of cities nominated for the award green capital from Turkey were discussed.

Keywords: Green Capitals, European Green Capitals, Open and Geen Areas, Green Area Policies. 
Nevşehir Bilim ve Teknoloji Dergisi (2019), 8(Enar Özel Sayı) 1-19

\section{Giriş}

Yeşil başkent kavramı kısaca bir markayı, bir unvanı, bir ödülü ifade etmektedir [1]. Avrupa Yeşil Başkenti ödülü, 2006 yılında Estonya’nın başkenti Tallinn'de 15 Avrupa kentinin (Tallinn, Helsinki, Riga, Vilnius, Berlin, Varşova, Madrid, Ljubljana, Prag, Viyana, Kiel, Kotka, Dartford, Tartu ve Glasgow) temsilcileri ile yapmış olduğu toplantı neticesinde, çevreyi iyileştirmek ve kentlinin yaşam kalitesini arttırmak, sürdürülebilirlik hususunda kentleri teşvik etmek, başka kentlere ilham vermek gibi amaçlarla başlatılan bir girişimin sonucudur. İlk adaylık süreci resmi olarak 22 Mayıs 2008 tarihinde başlamış ve ilk ödül 2010 yılında verilmiştir.

Yeşil başkent olmaya aday kentler 12 gösterge çerçevesinde değerlendirilmekte olup bunlar; 1-küresel iklim değişikliğine yerel katkı, 2-yerel ulaşım, 3-sürdürülebilir arazi kullanımını içeren yeşil kentsel alanlar, 4-doğa ve biyoçeşitlilik, 5-hava kalitesi, 6-gürültü kirliliği, 7-atık üretimi ve yönetimi, 8-su tüketimi, 9-atık su arıtma, 10-ekoyenilik ve sürdürülebilir istihdam, 11- enerji performansı ve 12- yerel yönetimlerin çevre performansıdır [2].

Avrupa Yeşil Başkenti seçilmek, kentlere ekonomik, ekolojik, sürdürülebilirlik, tanıtım gibi birçok alanda fayda sağlamaktadır. Ödül, Avrupa Komisyonu'nun belirttiği şekliyle; turizmde artış, uluslararası medyada yer alma, uluslararası düzeyde kentsel ilişkilerin kurulması, yabancı yatırımcıların dikkatini çekme, çevresel projelere dikkat çekme, çevresel sürdürülebilirliği devam ettirme ve vatandaşların gururu gibi konularda da kentlere fayda sağlamaktadır.

Başvurular karşılaştırıldığında ödüllü kentlerin, genelde 1 milyon nüfustan az, karbondioksiti azaltmada başarı elde etmiş, toplu taşım ve yenilenebilir enerjide yenilikçi yaklaşımlarıyla öne çıkmış, yeşil sistem kurma çabaları, atık ve su yönetimiyle bu unvana sahip kentler olduğu görülmektedir [3].

$\mathrm{Bu}$ çalışma kapsamında, yeşil başkent kavramı ve Avrupa Yeşil Başkentleri üzerinden açık ve yeşil alanlara yönelik politikalarının incelenmesi amaçlanmıştır. Kentler açısından fazlaca öneme sahip olan açık ve yeşil alanlar için kentsel yaşam kalitesini vurgulayan ve çevreci yönüyle dikkat çeken "yeşil başkent" kavramı ve bu kapsamda uluslararası tanınırlığı olan "yeşil başkent ödülü” irdelenmiştir. Bu ödülü kazanan kentlerin Türkiye'de yeterince tanınmadığı ve bu konuda Türkiye'de az sayıda araştırma yapıldığı gözlemlenmiştir. Mevcut çalışmaların da birçoğu tek bir yeşil başkenti incelemekle sınırlı kalmıştır [4], [5], [6], [7].

\section{Materyal ve Metot}

Bu çalışmanın materyalini, 2010-2020 yılları arasında Avrupa Yeşil Başkenti seçilen; Stolkholm (2010-İsveç), Hamburg (2011-Almanya), Vitoria-Gasteiz (2012-İspanya), Nantes (2013-Fransa), Kopenhag (2014-Danimarka), Bristol (2015- İngiltere), Ljubljana (2016- Slovenya), Essen (2017-Almanya), Nijmegen (2018-Hollanda), Oslo (2019Norveç) ve Lizbon (2020- Portekiz) kentleri oluşturmaktadır. Çalışmada literatür ve belge tarama yöntemi kullanılmış olup, Yeşil Başkent unvanına sahip olabilmek için gerekli olan 12 gösterge çerçevesinde konu değerlendirilmiştir. Hazırlanan "Yeşil Başkent" başvuru raporlarında bulunan "Yerel Ulaşım ve Sürdürülebilir Arazi Kullanımını İçeren Yeşil Kentsel Alanlar" başlıklı bölümler üzerinde yoğunlaşılmıştır. Yapılan incelemeler sonucunda ülkelerin yeşil alanlarına ilişkin temel politikaları değerlendirilmiştir. Ayrıca Türkiye'den yeşil başkent ödülü için aday gösterilen kentlerin açık ve yeşil alanlara yönelik uygulamaları tartışılmıştır. 


\section{Bulgular}

Çalışma kapsamında yapılan literatür çalışmaları sonucunda; 2010-2020 Yılları Avrupa Yeşil Başkenti Seçilen Kentlerin Yeşil Alan Politikaları belirlenmiştir. Bu politikalar doğrultusunda Yeşil Başkent ödülünü kente kazandıran bazı önemli noktalar vurgulanmıştır.

\subsection{Stockholm (2010-İsveç)}

Yaklaşı 800.000 (2008 verilerine göre) nüfusa ve kişi başı $87.5 \mathrm{~m}^{2}$ yeşil alana sahip olan Stockholm, uzun yıllar süren başarılı çevre çalışmaları ile dünyanın en temiz ve en güzel şehirlerinden biri olmuştur. Stockholm’un cazibesine katkıda bulunan önemli faktörlerden biri; vatandaşına kolay erişim ile rekreasyon, spor ve diğer açık hava etkinliklerini sunan; göller ve su yolları, yüzme ve balık tutma gibi olanaklar sağlayan çok sayıda yeşil ve mavi alana sahip olmasıdır. Estetik değerlerinin yanı sıra, Stockholm'ün yeşil alanları; vatandaşların sağlığına ve refahına aracılık ederek, gürültüyü azaltmaya, havayı filtrelemeye ve sulak alanlarından akan suyu arıtmaya yardımcı olmaktadır. Stockholm bölgesindeki kentsel alanlar, kentten çıkan parmaklar şeklinde oluşturulmuştur (Şekil 1). Stockholm'un doğusu yaklaşık 20.000 yeşil adaya sahip olan dünyaca ünlü takımadalar ile benzersiz bir doğaya sahiptir. Stockholm Belediyesi Araştırma ve İstatistik Dairesi'nden elde edilen veriler, belediyenin toplam alanının yaklaşık 22.000 hektar olduğunu ve bunların yaklaşık olarak 12000 ha (\% 55) yeşil alan ve 2800 ha (\% 13) su yüzeyinden oluştuğu bilinmektedir. Toplamda kentin yeşil-mavi alanları, tüm alanların \% 68'ini oluşturduğunu göstermektedir. Halkın \%95'i bir yeşil alana 300 metre mesafede, \%5'i de açık-yeşil çevre olarak sınıflandırılan müstakil evlerin bulunduğu bölgede yaşamaktadır.
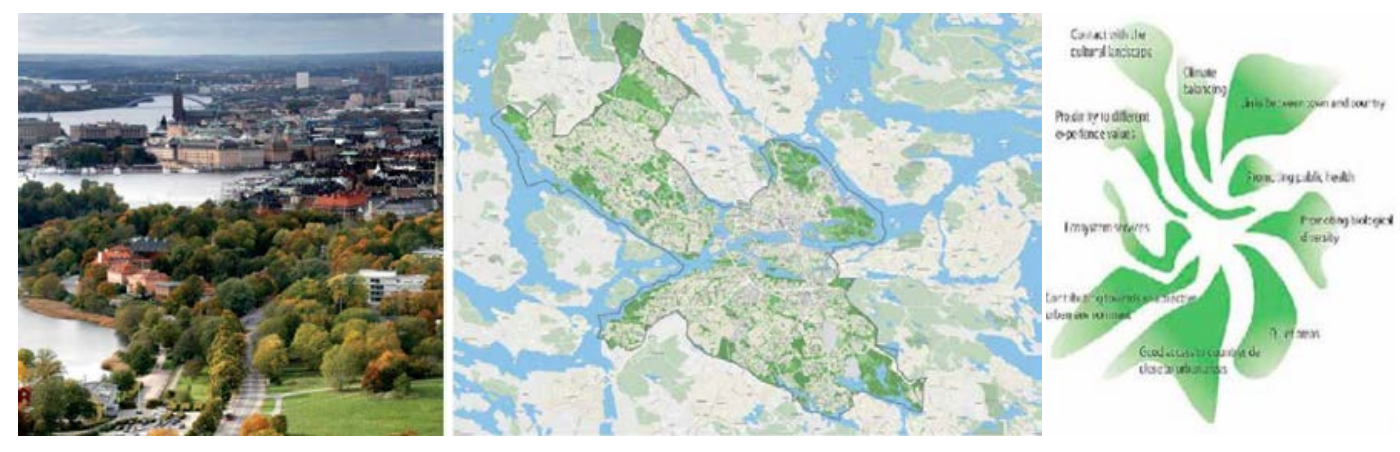

Şekil 1. Solda; Avrupa’nın ilk yeşil başkenti Stockholm, Ortada; Stockholm kent haritası [8], Sağda: Stockholm yeşil alanları kavramsal gösterimi [9].

Stockholm, Ekopark olarak da adlandırılan erişilebilirliği ve biyolojik çeşitliliği güvence altına alan doğal ve kültürel rezervleri ile dünyada benzersizdir. 1994 yılında, o dönemdeki ve gelecek kuşaklardaki doğasını ve kültürünü korumak için özel bir yasa çıkarılmıştır.

2006 yılında Stockholm Belediye Konseyi tarafından alınan bir kararın ardından ortaya çıkan, Stockholm parklarının ve yeşil alanlarının geliştirilmesi ve yönetimi için bir eylem programı olan Stockholm Park Programı ile park alanlarının "oynama, yürüme, güneşte dinlenme" vb. için sakinlere 200 metre mesafede bulunması gerektiği belirtilmiştir. 2008-2020 Çevre Programı ile arazinin sürdürülebilir kullanımı ve su alanlarına yönelik önlemlerle doğal değere sahip olan alanların korunmasına dikkat çekilmiştir. 


\section{Nevşehir Bilim ve Teknoloji Dergisi (2019), 8(Enar Özel Sayı) 1-19}

Stockholm Kapsamlı Arazi Kullanım Planı'nın koruma önlemleri ile biyolojik çeşitlilik ve erişilebilirlik gibi hedefleri vardır ve bugüne kadar, Çevre Yasası Mevzuatı çerçevesinde sekiz doğal rezerv alanı korunmaktadır.

Kentte tüm sokaklarda $30 \mathrm{~km} / \mathrm{s}$ hız sınırı vardır ve bu halkın bisiklet kullanımını teşvik etmektedir ve bu uygulama bisikletle seyahat oranını son on yılda (2000-2010) \%75 artırmıştır. Kent, bisiklet diğer ulaşım araçları kadar basit, kullanışı ve güvenli olmalıdır hedefiyle yola çıkarak Avrupa'da en önemli bisiklet şehirlerinden biri olmayı amaçlamaktadır ve 2007 yılında Stockholm, 'Bisiklet Kullanımını Destekleyen En İyi Şehir’ seçilmiştir. Kentin bisiklet yol ağı 2000-2010 yılları arasında 675km'den 760km'ye yükseltilmiştir [10].

\subsection{Hamburg (2011-Almanya)}

Hamburg toplam 75.524 hektar alana sahiptir ve 6.800 hektarlık yeşil alan (toplam alanın \% 9'u) ile Avrupa'nın en yeşil şehirlerinden biridir. Bunun dışında, şehrin sahip olduğu 3.432 hektarlık ormanlık alan (toplam alanın\% 5'i) ve 6.123 hektarlık doğa rezerv alanı (toplam alanın\% 8'i) bulunmaktadır ve toplam 14.563 hektar (Hamburg toplam alanın\% 19'u) ile 36 peyzaj koruma alanına sahiptir. Kentte kişi başı yeşil alan miktarı $17 \mathrm{~m}^{2}$ dir ve Hamburg nüfusunun yaklaşık \% 89'u bir yeşil alana en fazla 300 metre mesafede yaşamaktadır.
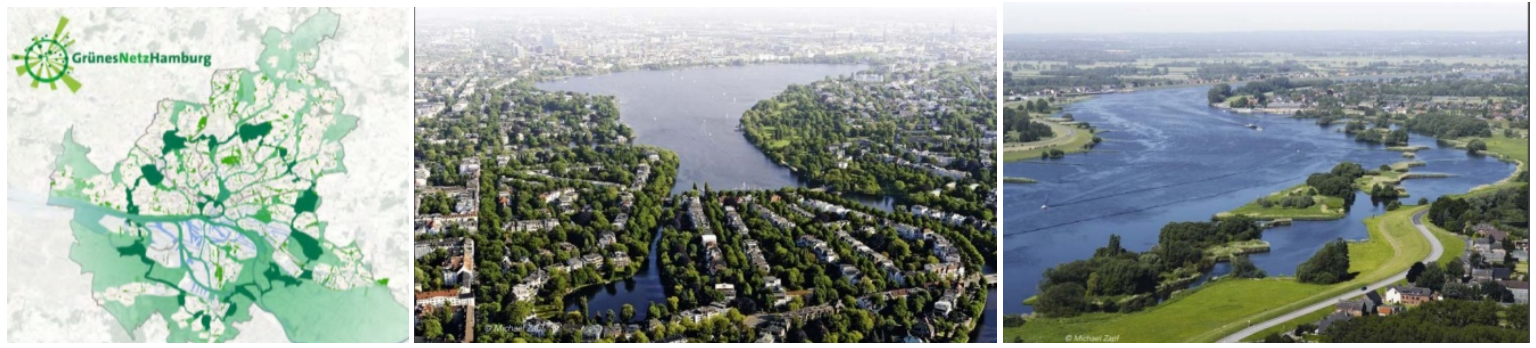

Şekil 2. Solda; Hamburg kenti yeşil alan ağı haritası [11], Ortada ve sağda; Hamburg mavi ve yeşil alanları [12].

Hamburg için kapsamlı bir kentsel açık alan konsepti dikkat çekmektedir. Ön şartı ağ bağlantılı açık- yeşil alan sistemi (green network veya ekolojik koridor), kentin ekolojik ve sosyal gelişimi ve kentin kendine özgü yapısal niteliklerinin korunması için ön plana çıkarılmıştır. Kentte radyal yatay eksenler ve iki teğet yeşil halka, açık alan ağının temel yapısal elemanlarını oluşturmaktadır. Yerleşim yerlerine uygun bir mesafede olan peyzaj eksenleri ve yeşil halkalar, parklar, oyun alanları, spor alanları gibi alanları içeren kompakt bir açık alan yapısı ile tamamlanmaktadır ve bu alanlar yeşil bir koridor vasıtasıyla birbirleriyle bağlantılıdır.

Hamburg'un parkları, Park Yasası (Grünanlagengesetz) ve Park Yönetmeliği (Grünanlagenverordnung) tarafından korunmaktadır. Kentin 29 doğa rezervi bulunmakta olup, 16'sı Fauna- Flora ve Habitat Direktifi (FFH Direktifi) uyarınca tamamen veya kısmen korunan alanlar ve 6'sı yabani kuşlar için tamamen veya kısmen korunan $A B$ Özel Koruma Alanları'dır (SPA'lar). Hamburg Orman Yasası kapsamında korunan ve yılda 50 milyon ziyaretçisi olan 500 km'lik orman yolu ile 4.400 hektarlık orman alanına sahiptir.

Kentin, yürüyüş yapmayı, bisiklete binmeyi ve flora ve faunanın doğal yayılımının teşvik edilmesi, kamusal yeşil alanların korunması ve geliştirilmesi için çevre dostu teknoloji ve malzemelerin kullanımı, değerli ağaç envanterinin korunmasına yönelik programların geliştirilmesi ve yönetimi, parklarda aileler ve yaşlılar için kullanım kalitesinin arttırılması, sosyal açıdan dezavantajlı mahallelerde açık ve yeşil alanların geliştirilmesi ve ağ oluşturulması, meydan ve yol kenarlarının iyileştirilmesi, okul oyun alanlarının yeniden yapılandırılması, şehrin biyolojik çeşitliliğinin korunması ve geliştirilmesi gibi hedefleri bulunmaktadır. 
Nevşehir Bilim ve Teknoloji Dergisi (2019), 8(Enar Özel Sayı) 1-19

Hamburg'da 30 yıldan beri var olan bisiklet yolu ağı 1755 km'dir ve bu kişi başı 1m'yi ifade etmektedir. Hamburg'da hemen hemen her yolda bisiklet sürmek mümkündür ve $30 \mathrm{~km} / \mathrm{s}$ hız sınırı olan bölgeler de dahil edildiğinde toplamda $3900 \mathrm{~km}$ uzunluğunda bisiklet hattı bulunmaktadır ve Hamburg'un en önemli merkezlerini birbirleriyle ve şehir merkezi ile birbirine bağlar. Hamburg'da 38 noktada yapılan sayımlarda yıllık bisiklet sayısı, 1984 'ten 2006'ya kadar, \%60 oranında arttığını göstermektedir [13].

\subsection{Vitoria-Gasteiz (2012-İspanya)}

Vitoria-Gasteiz $\left(276.8 \mathrm{~km}^{2}\right)$, yeşil kuşakla çevrili eş merkezli daireler şeklinde düzenlenmiştir. Kentte 1091 ha kamusal yeşil alan bulunmaktadır (kent alanının\% 32,67'si). Kompakt formdaki kentte yeşil kuşağın kent alanını tamamen çevrelemesi, kentin her bölgesinde yeşil alan varlığına ve erişilebilirliğine olanak sağlamaktadır. Halkın tamamı bir yeşil alana en fazla $300 \mathrm{~m}$ mesafede yaşamaktadır.

Vitoria-Gasteiz, kentsel planlarının hazırlanmasında nüfus artışının çevresel etkilerini dikkate almaktadır. Amaç, toprak kullanımının sadece ekonomik değil aynı zamanda çevresel olan kriterlere göre değerlendirilmesi gerektiği ilkesine uygun olarak iyi koordine edilmiş ve dengeli gelişim planları hazırlamaktır. Bu anlamda, 90'lı yılların ortalarında çakıl ocakları, tahrip olmuş alanlar, sulak alanlar vb. alanların dönüştürülmesi ile oluşturulan 613 hektarlık yeşil kuşağa ek olarak 2010 yllına kadar 478 hektarlık yeşil alan ilave edilmiştir. Yeşil Kuşağın (613ha) mevcut miktarı da dahil edildiğinde, kişi başına düşen yeşil alan miktarı $46.12 \mathrm{~m}^{2}$ olmaktadır. Kamusal alanın \%25'inden fazlası sadece yaya erişimi için ayrılmıştır ve kentsel alanda $33 \mathrm{~km}$ yeşil kuşak boyunca $91 \mathrm{~km}$ 'den oluşan farklı parklardan geçerek yeşil alanları birbirine bağlayan yaya ve bisiklet yolu vardır ve genel anlamda parklar, halka açık kullanım için tasarlanmış kent bahçeleri olarak düşünülmüştür. Kamusal kullanım konseptine ek olarak, yeşil kuşağın ekolojik ve peyzaj değeri yüksektir. Bu anlamda, kentsel yan alanların veya parkların ikisi, önemli doğal değerleri ile bireysel tanınmayı hak etmiş̧ir. Bunlardan biri Salburua sulak alanları LIC Bölgesi, Ramsar Uluslararası Önem Sulak Alanları, diğeri ise Natura 2000 Avrupa Ağı'nda LIC Bölgesi ilan eden Zadorra nehridir. Yeşil Kuşak projesi, 2000 ve 2004 Dubai'de en iyi uygulama olarak seçilmiştir.
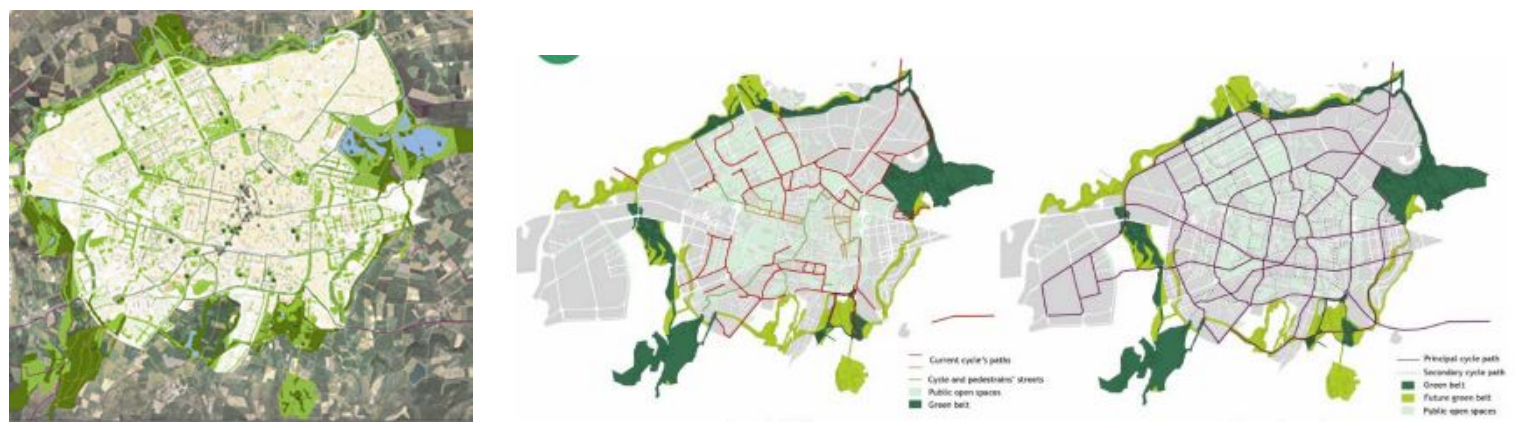

Şekil 3. Solda; Vitoria-Gasteiz kenti yeşil ağı, sağda; bisiklet yol ağının mevcut durumu ve gelecek planı [14].

Kentte yeşil alanlarının geliştirilmesi ve sürdürülmesi için yapılan uygulamalar dikkat çekmektedir. 2002 yılında, yeni kentsel yeşil alanların yaratılması ve tasarlanmasına ilişkin sürdürülebilirlik kriterleri ve kısıtlamaları getirmek amaciyla Kentsel Peyzaj Ofisi kurulmuştur. 2003 yllında, kentsel yeşil bölgelerin düzenlenmesi, kent ağaçlarının yönetimi ve korunması, kentin gelişme alanlarında yeşil alanların yaratılması için Yeşil Alanlar Eylem Planı hazırlanmış ve üç yeni tüzük onaylanmıştır. Turizm, ekolojik ve spor rotaları olarak kullanılması için bir Ekolojik Yollar Sistemi oluşturulmuştur. 2006 yılında, Vitoria Dağları gelecekteki gelişimden ve diğer yasadışı kullanımlardan korunması amacıyla Tabiat Parkı olarak ilan edilmiştir. Yeşil alanların yönetilmesini ve sürdürülmesini kolaylaştırmak için dijital bir envanter oluşturulması amacıyla özel olarak tasarlanmış bir uygulama geliştirilmiştir. Sürdürülebilir 


\section{Nevşehir Bilim ve Teknoloji Dergisi (2019), 8(Enar Özel Sayı) 1-19}

Hareketlilik ve Kamusal Alan Planı ile ana hareket noktalarının yürüyerek bağlanması ve bu amaç doğrultusunda, mevcut demiryolu tarafından kullanılan arazinin dönüştürülmesi ve Yeşil Kuşak ile bağlantılı olarak doğudan batıya yüksek kaliteli bir yaya geçidi yapılandırmasına izin verecek şekilde demiryolu hattı yeraltına alınmış̧ır. Yaya ölçekli küçük bir şehir olan Vitoria-Gasteiz, vatandaşlarına yüksek yaşam kalitesi sunan sürdürülebilir bir şehir olmak için politika geliştirme ve uygulama konusundaki hedeflerine güçlü bir bağlilığa sahiptir. Şehirdeki toplam nüfus sayısına bağlı olarak belirlenen bisiklet yollarının uzunluğu, 2002'de kişi başı 0,05 m iken 2010'da 0,41 m'ye yükselmiştir [15].

\subsection{Nantes (2013-Fransa)}

Nantes, kent bütününde kişi başı $57 \mathrm{~m}^{2}$ ve kent merkezinde kişi başı $37 \mathrm{~m}^{2}$ ile toplamda 3.366 hektarlık yeşil alandan oluşmaktadır. Şehrin tam ortasındaki çapraz bölgede biyoçeşitlilik koridorlarını destekleyen, dikkate değer ve çok kapsamlı bir hidrografik ağ (46 kilometresi Nantes sınırlarında olan toplamda 250 km'lik su yolu) bulunmaktadır. Biyoçeşitliliği iyileştirmeyi mümkün kılan, korunan tüm alanlarda farklılaştırılmış çevre yönetimi uygulanmaktadır. Kentte, 1999'dan beri halkın tamamı bir yeşil alana en fazla 300 m mesafede yaşamaktadır.

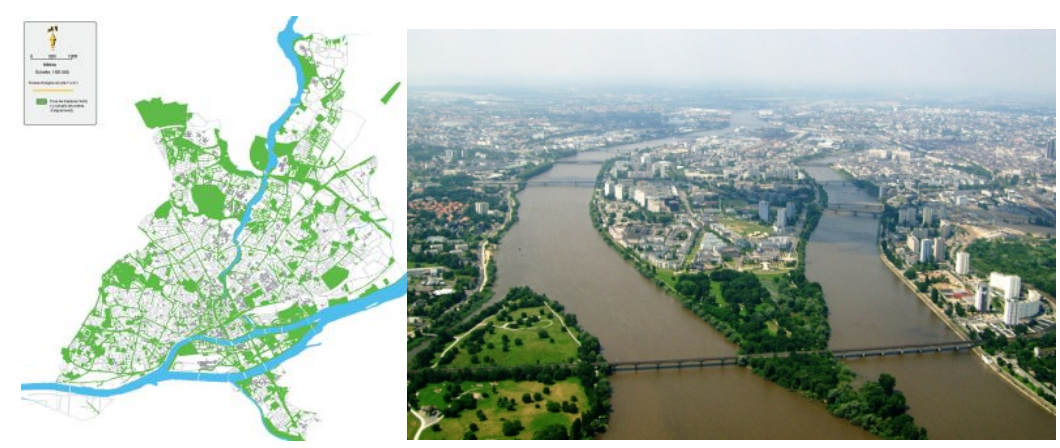

Şekil 4. Solda; Nantes yeşil ağı haritası [16], sağda; Nantes mavi ve yeşil alanının kent ile uyumu [6].

\subsection{Kopenhag (2014-Danimarka)}

Kentin açık-yeşil alanları, 200 hektarı göl ve su alanı olan yaklaşık 2.260 hektar yeşil alan, 92 km sahil şeridi ve $14,7 \mathrm{~km}$ açık su yolu ile kentin toplam alanının \%25'ini oluşturmakta ve kişi başı $42.4 \mathrm{~m}^{2}$ yeşil alan düşmektedir. Halkın \%80'i bir yeşil alana en fazla 300 m mesafede yaşamaktadır. Kopenhag'da parklar halkın ortak bahçesi ve kentin en önemli konaklama alanları olarak kabul edilmektedir ve halka boş zamanlarını geçirme firsatı sunmanın önemli olduğuna inanılmaktadır. Bu nedenle daha iyi yeşil alan yaratma konusunda gönüllü olan vatandaşların girişimlerini destekleyecek projeler yapılmaktadır. Bu projeler arasında yerel tarım bahçeleri, yeşil hareketlilik ve çeşitli yeşil etkinlikler yer almaktadır.
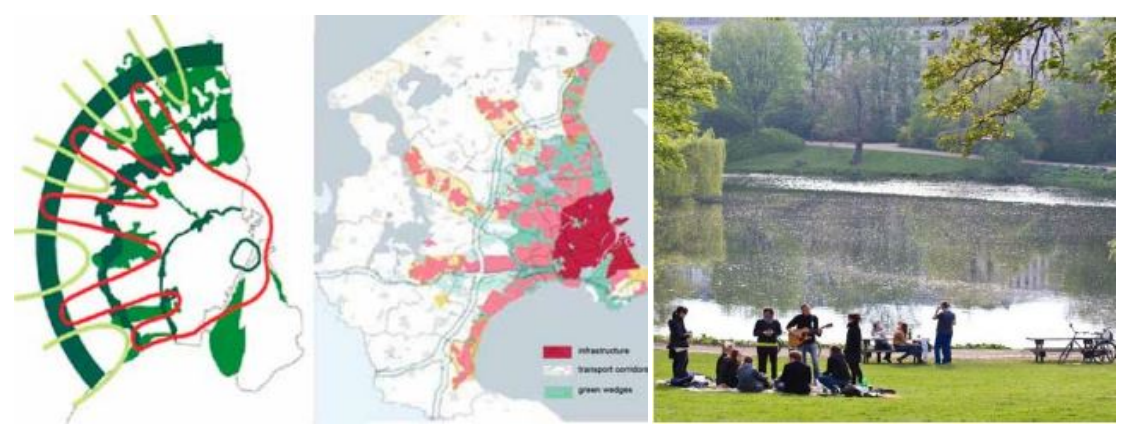

Şekil 5. Solda; Kopenhag Parmak Planı [9], sağda; Kopenhaglıların gündelik yaşam kalitesini yükselten açık ve yeşil alanlar [1].

Kentin yeşil alanlarının geliştirilmesi ve sürdürülmesi için birçok uygulama yapılmıştır. 2004 yılında 'Yeşil Kopenhag Park Politikası' oluşturulmuştur. 'Yeşil ve Mavi Başkent' teması ile 2007 yılında 'Eko-Metropol Kopenhag 


\section{Nevşehir Bilim ve Teknoloji Dergisi (2019), 8(Enar Özel Sayı) 1-19}

2015 Vizyonu’ yayımlanmıştır. 2009 yılında ‘Cep Parkları ve Diğer Yeşil Alanlar Eylem Planı’ işleme konulmuştur. Nüfusun 2025 yılına kadar 100.000 artması tahmin edilerek 2009 yılında kentin tüm park ve doğal alanlarının Doğa Koruma Yasası'na göre listelenmesi sağlanmıştır. Çevresel olarak uygun yoğunluğu ve yeşil alanlara kolay erişim sağlamak amacıyla kentsel tasarımda yeni yapılacak çok aileli konutlar geliştirilmiştir. Bu konutlar $100 \mathrm{~m}^{2}$ konut alanına $60 \mathrm{~m}^{2}$ yeşil alan olacak şekilde (otopark çoğunlukla binaların altındadır) tasarlanmıştır. Konutlar için garaj ve park alanlarını yıkarak yeşil alanlar oluşturulması, tüm yeni kentsel gelişim alanlarında düşük enerjili konut tasarlanması hedeflenmiştir. 2009 yılında 'kentin yeşil akciğeri' olarak anılan Faallenparken'ın yenilenmesi, 2011 yılında oyun alanlarının yenilenmesi için 'Oyun Odaları' projesi hayata geçirilmiştir. İklim adaptasyonunu sağlamak, Kopenhag'ın geleceğini güvence altına almak, daha fazla ağaç, yeşil çatılar, iklime dayanıklı yeşil ve mavi yüzey önerileri ile 2011 yılı İklim Değişikliği Uyum Planı oluşturulmuştur.

Kopenhag, bisiklet şehri olma, geliştirilmiş toplu taşıma, trafik sakinliği ve park yeri kısıtlamaları, düşük emisyon bölgeleri ve çevre dostu araçlar gibi hedefleri ve ulaşım politikaları ile de yeşil kent olma hedeflerini desteklemektedir. Şehir için günümüze kıyasla çok daha az çevresel etkiye neden olan tamamen işlevsel bir ulaşım sistemi sağlamak amacıyla 2004 Ulaşım ve Çevre Planı oluşturulmuştur. Kopenhag'da insanların \%50'sinin iş veya okullarına bisikletle gitmesini hedefleyen Eko-Metropol 2007 politikası geliştirilmiştir [17].

\subsection{Bristol (2015- İngiltere)}

Bristol, çok işlevli, birbirine bağlı yeşil alanlardan oluşan bir ağa sahiptir ve vahşi yaşam, rekreasyon, aktif seyahat ve doğal ortamdaki değişikliklere uyum için bu bağlantıyı sürdürmenin, geliştirmenin ve planlamanın gerekliliğine önem vermektedir. Kentin \%34'ü yeşil ve mavi alanlardan oluşmaktadır. 4 şehir çiftliği, 8 doğa rezerv alanı ve 400'den fazla park bulunmaktadır. Halkın \%88'i, şehir içi nüfusunun \%87'si de dahil olmak üzere, bir yeşil alana $300 \mathrm{~m}$ mesafede yaşamaktadır.
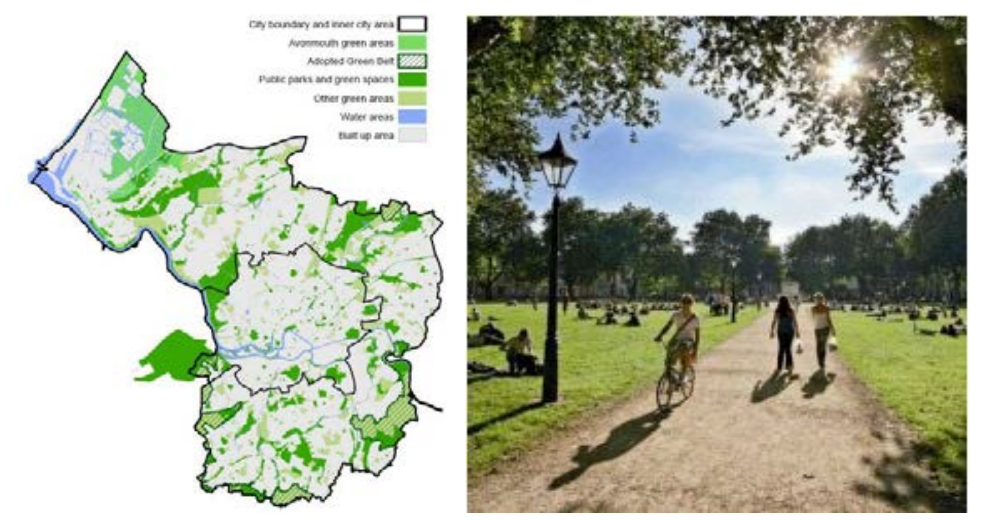

Şekil 6. Solda; Bristol kenti mavi-yeşil ağı haritası, sağda; Bristol kenti açık yeşil alan kullanımları [18].

Bristol'deki arazi kullanımı 1000 yıllık kentsel tarihi yansıtmaktadır. Şehir 1700'den 1950’ye kadar hızla büyümüştür ve bu durum yeşil alanların parçalanmasına yol açmıştır. O zamandan beridir Bristol kalkınmaya rehberlik etmek ve yeşil alanları korumak için arazi kullanım politikalarını benimsemiştir. Nüfus artışı kentin yeşil alanları üzerinde artan bir baskı oluşturmuştur bu nedenle kentsel büyüme kentin etrafındaki yeşil kuşak ile sınırlandırılmıştır. Kamusal yeşil alanların kalite ve erişiminin arttırılması için 2006-2026 Parklar ve Yeşil Alanlar Stratejisi benimsenmiştir. Kompakt gelişim ve yüksek arazi değerleri nedeniyle şehir içinde yeşil alana ulaşım zor olmasına karşın Bristol'de Avon Boğazı üzerinde kurulan köprü sayesinde halk yeşil alana şehir merkezinden birkaç dakika içerisinde ulaşabilmektedir. 


\section{Nevşehir Bilim ve Teknoloji Dergisi (2019), 8(Enar Özel Sayı) 1-19}

Nehirleri, vahşi yaşam koridorlarını, parkları ve yeşil alanları korumak ve geliştirmek amacıyla Stratejik Yeşil Altyapı Sistemi oluşturulmuştur. Bu kapsamda; 1-Kentte rekreasyon için açık yeşil alanlar sağlamak ve geliştirmek, 2Yeşil altyapı ağına bağlantılar ve su yolları boyunca erişimin sağlanması, 3-Kentteki vahşi yaşamın kalitesi, eğitim ve öğretim açısından rolünün tanınması gibi doğa ile etkileşime girme olanağı sunulması, 4-Bristol Vahşi Yaşam Ağı'nın şehir planı tarafından korunması ve 5-Şehirdeki ağaç kanopi örtüsünü uzun vadede \%14'den \%30'a çıkarmayı ve 2012 yılında iddialı bir ağaçlandırma projesi ile sokak ağaçlarının sayısını 3 yılda $\% 20$ artırmayı hedeflemiştir.

Bristol belirlediği hedefler doğrultusunda yeşil ekonomide 2012 yllında \%4.7’lik bir büyüme gerçekleştirmiştir, bisiklet kullanımını iki katına çıkarmıştır ve 2020 yılına kadar bu sayıyı iki katına daha çıkarmayı hedeflemektedir. Bisiklet şehri olarak bilinen İngiltere'de 2008-2011 yılları arasında 22 milyon avro yatırım yapılmıştır. Bristol'deki bisiklet altyapısını önemli ölçüde arttırmanın yanı sıra, hedef, Birleşik Krallık’ta bisiklet kullanımında yıllardır süren düşüşün üstesinden gelen bir etki yaratmaktır. Bu kapsamda, 61 km'si ayrılmış yol olan 200 km'lik bisiklet ağı, şehirdeki konut alanının 1/6'sını kaplayan 2 pilot alan, çocuklar için eğitim, bisiklet festivalleri ve kültürel etkinlikler, düşük gelirli insanlara ve mahkumlara yönelik bisikletlere erişimin sağlanması için bisiklet binme programları, kredili bisiklet kullanımı gibi stratejiler belirlenmiş ve sonucunda 2007-2010 yıllarında bisiklet kullanımında $\% 80$ oranında artış meydana gelmiştir. Ayrıca daha fazla bisiklet ve yürüme gibi aktif seyahat etmeyi teşvik etmek ve kolaylaştırmak gibi 2026 yılını hedef alan stratejileri bulunmaktadır [18].

\subsection{Ljubljana (2016-Slovenya)}

Doğal özellikleri ve iyi düşünülmüş şehir planlaması sayesinde, Ljubljana kendine özgü bir yeşil kimliğe sahiptir. Mekansal plan, yeşil alanların Ljubljana şehrinin yaklaşı \% 75 'ini oluşturduğunu göstermektedir. Tüm yeşil alanların yaklaşık \% 81'i, yeşil kamalar ve nehir koridorları ile tarihi şehir merkezine yayılmaktadır. Diğer yeşil alanlar (\%19) kompakt kent içerisinde bahçe, park, oyun alanları ve apartmanlar arasında bulunmaktadır. Yeşil alanlar öncelikle kentin engebeli, bataklık ve sulak alanlarına yani inşaat ve kentsel gelişimin daha az çekici olduğu alanlara bağlanmıştır. Tüm şehirde, yeşil alanlar eşit olarak dağıtılmıştır. Yeşil kamanın rolünün ve aralarındaki bağların çok önemli olduğu vurgulanmaktadır. Ljubljana kent merkezi kişi başı $106 \mathrm{~m}^{2}$ yeşil alana veya $66 \mathrm{~m}^{2}$ kamusal yeşil alana sahiptir ve neredeyse tüm yerleşim alanları kamusal açık yeşil alana $300 \mathrm{~m}$ mesafede bulunmaktadır. Kent $10 \mathrm{~m}^{2}$ ile 2 ha arasında değişen özel yeşil alanlar ve çocuk oyun alanlarından, $1 \mathrm{~m}^{2}$ ile 30 ha arasında değişen yeşil alanlar ve 100 $\mathrm{m}^{2}$ ile 500 ha arasında değişen orman alanlarından oluşmaktadır. Ljubljana, şehir bütçesinin \%3’ünü oluşturan 180 ha'lık açık yeşil alana sahiptir (2016 yılı verilerine göre). Kentteki yeşil alanların çoğunluğu (\%96'sı) mülkiyeti ne olursa olsun (özel bahçeler hariç) halkın kullanımına açıktır. Yeşil alanların kent sağlığı, hoş çevre ve yaşam kalitesi için çok önemli olduğu vurgulanan kentte 2005 'den beri halka açık yeşil alanların oluşturulmasına özel önem verilmektedir.

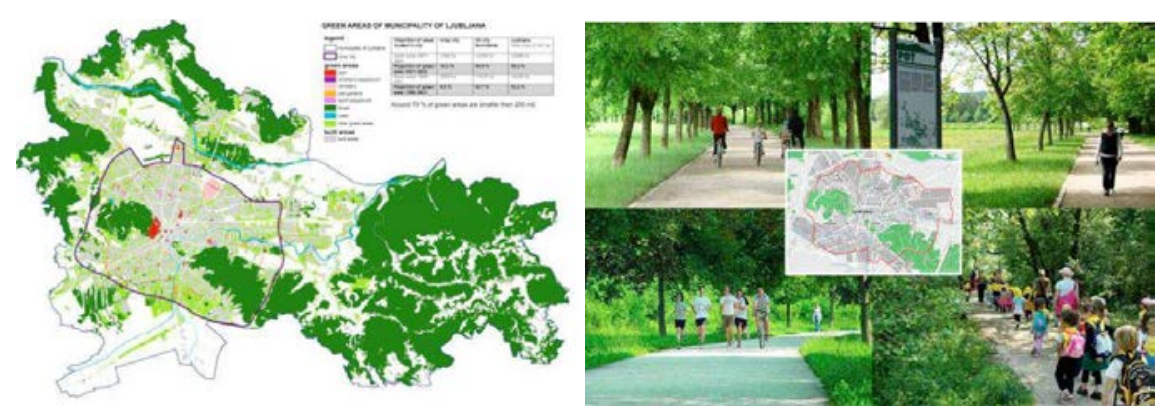

Şekil 7. Solda; Ljubljana kenti yeşil alan ağı haritası, sağda; kentin yeşil alanları kullanımı [19]. 
Nevşehir Bilim ve Teknoloji Dergisi (2019), 8(Enar Özel Sayı) 1-19

Ljubljana yeşil ve açık alanlara yönelik olarak hedef ve politikaları ile dikkat çekmektedir. Şehir merkezini çevresi ile birbirine bağlayan, şehirdeki beş potansiyel yeşil kamanın tümünü düzenlemek ve korumak ayrıca yeşil alan ağlarını entegre bir yeşil alan sistemine bağlaması bu hedeflerden ilkidir. İnsanların yaşam ve rekreasyon kalitesinin arttırmak amacıyla tüm sakinler için yeşil alanların erişilebilirliğinin ve eşit dağıtımının sağlanması diğer bir hedef olarak görülmüştür. Bu hedef ve politikalara ilaveten, yeşil alanların özel bir unsuru olan su kenarları kurmak ve bu alanların düzenlenmesi, kentsel ortamda yeterli iklim, hava ve ekolojik kalitenin sağlanması, sürdürülebilir bir şekilde kişi başına $2.5 \mathrm{~m}^{2}$ kapalı, $3 \mathrm{~m}^{2}$ açı spor ve rekreasyon alanı düşecek şekilde planlanma yapılması ve eski konut alanlarının $\% 50$ konut $\% 50$ yeşil alan olacak şekilde yeniden oluşturulması gibi hedef ve politikalar da bulunmaktadır.

Ljubljana, büyüklüğü ve coğrafi koşulları nedeniyle bisiklet kullanımı için son derece uygundur ve 190 km'lik bisiklet yolu ağı bulunmaktadır. 2006-2013 yılları arasında $42 \mathrm{~km}$ yeni bisiklet yolu, 837 bisiklet standı oluşturulmuş ve 2011 yılında 308 bisiklet ile 33 self-servis bisiklet paylaşım istasyonu kurulmuştur. 2020 yllında Ljubljana, Dünya Amatör Bisiklet Şampiyonasına ev sahipliği yapacaktır [19].

\subsection{Essen (2017-Almanya)}

Almanya'da hava kirliliği, toprak, su kirliliği ve madencilikten kaynaklanan çevresel problemler nedeniyle 1923 yılında açık ve yeşil alanları korumak amacıyla bölgesel yeşil alan planları yapılmaya başlanmıştır. Ayrıca kamusal yeşil alan sistemi geliştirmek için ilk planlama çalışmaları Essen'de yapılmıştır. Bu yeşil alan sistemi başlangıçta bireysel yeşil alanlardan ve rekreasyon için büyük öneme sahip olan şehir ve bölge parklarından oluşmaktaydı. Kentsel ve açık alan planlama sürecinin amacı, işlevsel bir yeşil alan sistemi oluşturmak için ileriye dönük bir yeşil alan kalkınma politikasını kullanmaktı. Bu nedenle 1960’larda meydana gelen kömür krizi ile maden ocaklarının kapanması ve 1970'den sonra çelikhaneler ve ilgili sanayi kuruluşlarının kapanması ile bu alanların yeşil alana dönüşümü sağlanarak bu güne kadar devam eden yeniden yapılanma süreci başlatılmıştır. 1975’ten itibaren yeşil alanların şehrin kuzey yarısına yayılması sağlanmıştır. Başlangıçta 'Yeşil 14' daha sonra ' Kuzey Essen Planı' adı altında, çoğunlukla eski sanayi tesisleri ve kömür madeni alanlarından oluşan ve 100 'den fazla yeşil alan içeren yaklaşık 400 hektarlık yeşil alan sistemi oluşturulmuştur. Şehir genelinde ekolojik ağ oluşturma ve sürdürülebilir kentsel iyileştirme için 2000 yılından itibaren bazı projeler uygulamaya geçirilmiştir. Bunların en önemlilerinden biri, akarsular boyunca yeni kamusal açık alan planlaması ve geliştirilmesi amacıyla Emscher Nehri için 'Emscher Sisteminin Dönüştürülmesi’ projesidir. Su yüzeylerinin gelişimi, yağmur suyunun geri kazanılması, yeni yeşil alanlar inşa edilmesi, mevcut olanların dönüştürülmesi, su ve bisiklet yollarının suya bağlı malzemelerle genişletilmesi ve yenilenmesi gibi 500'den fazla bireysel önlemi içeren 'Essen Yeni Su Yolları Eylem Planı' bir başka proje olarak hayata geçirilmiştir. Bu projelerle kentte banliyö alanları kamusal yeşil alanlarla birbirlerine bağlanmıştır.

Essen halkının neredeyse tamamı büyüklüğü $5000 \mathrm{~m}^{2}$ den büyük olan bir kamusal yeşil alana en fazla $300 \mathrm{~m}$ mesafede yaşamaktadır. Kent $150 \mathrm{~km}$ uzunluğunda yeşil ana ulaşım ağına sahip olup yeşil alanlar sadece yerleşim alanlarını değil aynı zamanda komşu şehirleri de birbirine bağlamaktadır. $500 \mathrm{~m}$ yarıçap içerisinde ortalama 250.000 kişi yeşil ağa ulaşabilmektedir. 2007-2014 yılları arasında yeşil altyapıya 50 milyon Euro'dan fazla yatırım yapılan Almanya'nın en büyük üçüncü yeşil şehri olan Essen, yeşil ve açık alanları ile şehir alanının \%53'ünü oluşturmaktadır. 

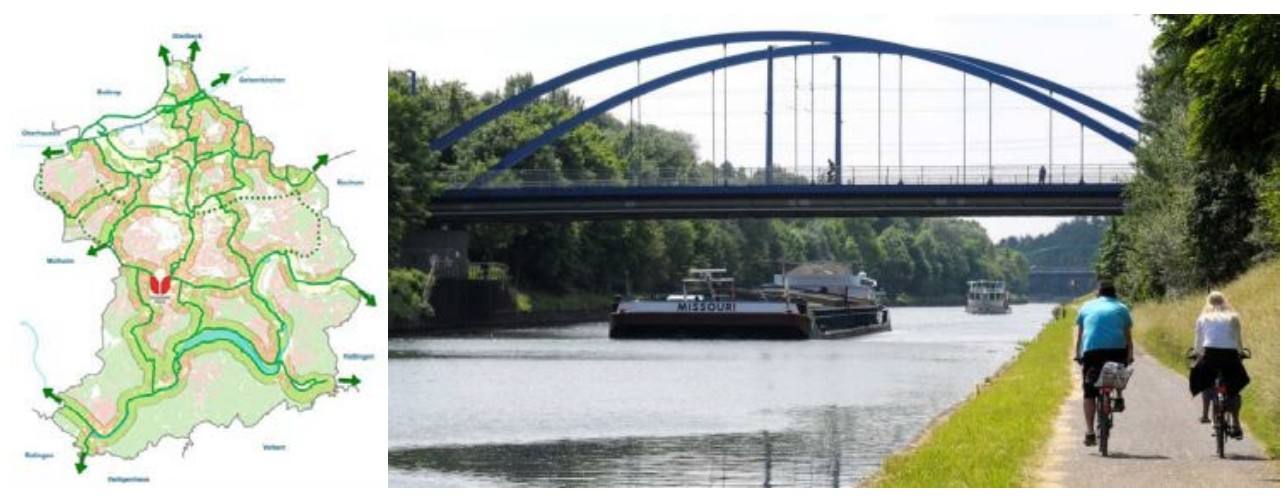

Şekil 8. Solda; Essen kenti yeşil aksları, sağda; mavi-yeşil alarlar arası bağlantı ve bu alanların rekreasyonel kullanımı [20].

Yeni bölgeler ekolojik tasarım ilkelerini, iklim değişikliğine adapte edilmiş tasarım planları, sürdürülebilir enerji kavramlarını, taşkın korumasını iyileştirmek için yağmur suyunun kullanımı ve geri kazanılması, toprak koruma önlemlerini ve motorsuz taşıtın tanıtımını dikkate almaktadır bu aynı zamanda yeni ilçelere 'yeşil yol ağı' ile bağlantı kurulmasına da olanak sağlamaktadır. Bu amaca, Duisburg'daki Ren bölgesinden Essen üzerinden Hamm’a kadar uzanan tüm Ruhr Bölgesi'nden geçen bölgesel bir proje olan 101 km'lik Ruhr hızlı bisiklet yolu da hizmet vermektedir. Kentin, yeşil planlamanın şehre ve bölgesel kalkınma süreçlerine dahil edilmesiyle, gelecekte yaşam kalitesi ve eğlence ile yeşil bir şehre dönüşmesine devam etmesi planlanmaktadır.

Essen, İkinci Dünya Savaşı'ndan sonra ulaşım sistemini bisiklet yolları ile birlikte planlamıştır ve kent, yol ağı kişi başı 0.19 metre ile toplamda $110 \mathrm{~km}$ bisiklet yoluna sahiptir. Buna ek olarak ana ulaşım ağ 1 dişında $262 \mathrm{~km}$ 'lik bisiklet yoluna sahiptir ve 2020 yılını hedef alan çok sayıda politika ve kampanyaları bulunmaktadır [20].

\subsection{Nijmegen (2018- Hollanda)}

Hollanda'nın en eski ve Roma sınır kenti olan Nijmegen, 1875 yılına kadar Waal nehri kıyısında hoş bir konuma sahip olan 23.000 nüfuslu bir kent konumundaydı. 1990’a kadar radyal yol yapısı ile yarım eş merkezli bir daire şeklinde gelişmiştir ve bugün 170.000 'den fazla nüfusu ve $3.000 / \mathrm{km}^{2}$ nüfus yoğunluğuyla büyüyen bir şehirdir. Şehrin ana odak noktası, şehir için hem önemli zorluklar hem de firsatlar sağlayan Waal nehridir.
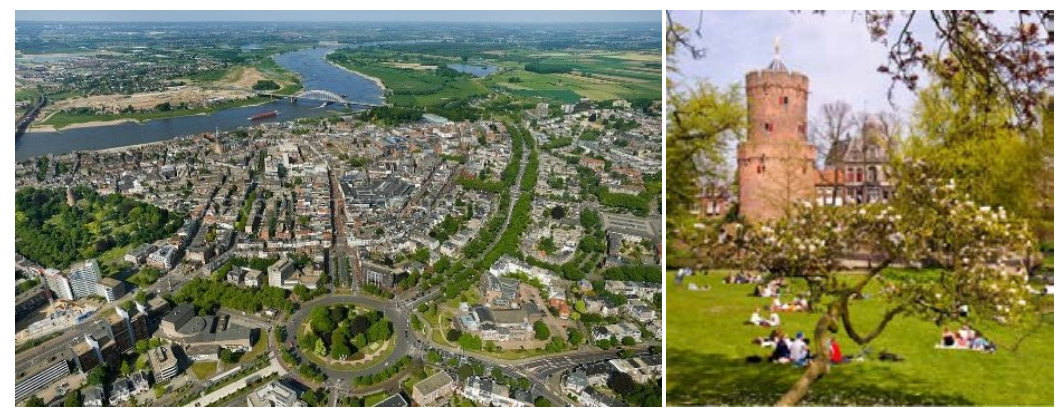

Şekil 9. Solda; Nijmegen yeşil ve mavi alanı, sağda; Nijmegen halkının yeşil alan kullanımı [21].

Kentte 1950'lerde konut başına kamusal yeşil alan miktarı $92 \mathrm{~m}^{2}$, kişi başı yeşil alan miktarı ise $40 \mathrm{~m}^{2}$ 'dir. 2015 verilerine göre; kent bütünündeki halkın \% 96's1, şehir merkezindeki halkın \% 90’1, en az 5000 m²'lik bir yeşil alana en fazla 300 m mesafede yaşamaktadır.

Nijmegen, 2045'te enerji nötrlüğü ve 2050'de iklime dayanıklı olma hedeflerine ulaşmak için Yapısal Vizyon 2013 'ü benimsemiştir. Şehir ayrıca yeşil ve mavi altyapı ve biyolojik çeşitlilik projelerinin geliştirilmesine sivil katılımın arttırılması için 'Yeşil Bağlantılar' adlı bir kampanya yürütmüştür ve bisiklet altyapısı ile birlikte, kentsel 


\section{Nevşehir Bilim ve Teknoloji Dergisi (2019), 8(Enar Özel Sayı) 1-19}

gelişim ve çevre yönetimler ile mekansal uyum için temel, bağlayıcı bir yapı oluşturmayı hedeflemiş̧ir. Nijmegen, su yönetimi, kentsel dönüşüm vizyonu ve tasarımıyla dünya çapındaki 2012 Waterfront Ödülü’nü almıştır. Yeşil alanlarında görüntü kalitesine önem verilen kent, Görüntü Kalite Komitesi tarafından sıkı bir incelemeye tabi tutulmaktadır. Kent ödül alana kadar ki süre içerisinde yeni yeşil alanların inşasına, kent merkezinin yeşil alan miktarının artırılmasına, yeni suyollarına ve yeşil çatı projelerine önemli yatırımlar yapmıştır. Yeşil politika, De Groene Draad (2007) politika planında ortaya konmuş ve Nijmegen, yeşil ve mavi alanlar kapsamı ve iklim kalitesi, eğlence, spor, sosyal uyum, sağlık ve şehir pazarlaması gibi gereklilikleri karşılamalıdır düşüncesiyle kentsel düzeyde fırsatlar ve çerçeveler oluşturmuş bu hedefler doğrultusunda kent, 2020 yılına kadar bölgelere ayrılmıştır. Nijmegen destekleyici yapılar olarak, sürdürülebilir enerji ve iklim adaptasyonu ile sürdürülebilir mekansal gelişimi tercih etmektedir.

Nijmegen’de yeşil alanlarına yönelik birçok hedef ve politika belirlenmiştir. Kompakt şehir formu ile şehir merkezindeki yeşil-mavi eksenin doğaya ve nehre uygun olarak sürdürülmesi amaçlanmaktadır. Ayrıca her eve $300 \mathrm{~m}$ mesafede 0.5 ha yeşil alan planlanmaktadır. Şehri çevreleyen yeşil halka üzerinde komşu belediyeler ile birlikte çalışılması, bisikletle kolay erişim sağlanması hedeflenmektedir. Arazinin yeniden yapılandırılması için toprak, su, hava, arkeoloji ve gürültü için geçerli yasal çerçevenin oluşturulması bir başka hedef olarak görülmektedir. Yeşil alanların oluşturulması ve bakımında yerel halkın katılımının sağlanması ve Belediye Kanalizasyon Sistemi Planı (2017-2022) ile yağmur suyunun arıtılması, sürdürülebilir su kullanımı ve yeşil çatıların teşvik edilmesi gibi öncelikli hedefleri bulunmaktadır.

Nijmegen'da 2005 yılı verilerine göre, şehir içi seyahatlerin \%37'si bisikletle yapılmıştır ve buna bağlantılı olarak kısa mesafede özel araç kullanımı önemli ölçüde azalmıştır. Bisiklet trafiği, toplam uzunluğu 79km olan şehirden bağımsız bir otoban yolu ağı tarafından teşvik edilmektedir ve bisiklet yolları şehir sınırlarında bitmemekte çevre kasaba ve köylere bağlanmaktadır. Kentte, bisiklet ulaşımını kolaylaştırmak için bisiklet tünelleri ve bisiklet köprüleri inşasına önem verilmektedir [22].

\subsection{Oslo (2019-Norveç)}

Oslo, yaklaşık 650. 000 nüfusa ve geniş bir araziye sahiptir. 1934 yllına dayanan planlar, kentte sürdürülebilir taşımacılı̆̆a katkıda bulunan 220 km'lik yeşil yol oluşturulmasının temelini oluşturmaktadır. Şehir, ulusal olarak korunan bir bölge olan Marka Ormanı ve her ikisi de birkaç suyolu ile bağlantılı olan Oslo Fiyordu ile çevrilidir. Oslo'nun doğal alanlarını koruma ve suyolu ağını geri kazanma yaklaşımı, 2019 Avrupa Başkenti Ödülü'nü kazanmasının birçok nedeninden sadece biridir.

Oslo'da kamusal ve özel yeşil alan ayrımı yoktur bu nedenle tüm yeşil alanlar mülkiyeti ne olursa olsun halka açıktır. Halkın \%98'i bir yeşil alana en fazla 300 metre mesafede yaşamaktadır. Oslo'nun mavi ve yeşil alanları, on ana suyolu ile birlikte yapılı çevrenin \%21'ini oluşturan kapsamlı bir park, dinlenme alanı ve yeşil koridor ağını içermektedir.

Oslo, kompakt kentsel gelişim, mavi-yeşil altyapı yatırımları ve diğer yeşil alanlardaki iyileştirmelerle artan nüfustan kaynaklanan sorunlara çözüm üretmiştir. Buna ek olarak, kentsel tarım programlarını genişleterek yerel mahalleleri de devreye sokmuş, yol ve bisiklet ağını iyileştirmiş, kopuk bağlantı noktalarını yeniden inşa etmiş böylece karayolları ve demiryolları üzerinde güvenli geçitler oluşturarak engellerin kaldırılmasına odaklanmış ve yüksek nüfus artışına rağmen, otomobil trafiğinin ulusal ortalamanın altında kalmasını sağlamıştır. Kent, her sakinin temiz hava, temiz su ve rekreasyon alanlarına erişilebilirliği ile sürdürülebilir bir şehir olma hedefine ulaşmasını sağlayan Kentsel Ekoloji Programı ile desteklenmektedir ve İklim Adaptasyon Stratejisini de tamamlayan ilk Norveç şehridir. Yağış miktarı ve sürelerinin yüksek olması nedeniyle yağmur suyu yönetimi iklim değişikliğine uyum için birinci öncelik 


\section{Nevşehir Bilim ve Teknoloji Dergisi (2019), 8(Enar Özel Sayı) 1-19}

olarak belirlenmiştir ve bu doğrultuda şiddetli yağmur sırasında akarsu havzalarında güvenli akıntı kanallarının oluşturulması, yeşil çatılar, yağmur yatakları, hendekler ve geçirgen yüzeylerin inşası ile yüzey akışının sağlanması amaçlanmıştır. Oslo'da toplamda $271.000 \mathrm{~m}^{2}$ 'lik çatı alanını temsil eden yeşil çatılı yaklaşık 500 bina tespit edilmiştir ve bunların $140.000 \mathrm{~m}^{2}$ 'si bitkilerle kaplıdır.
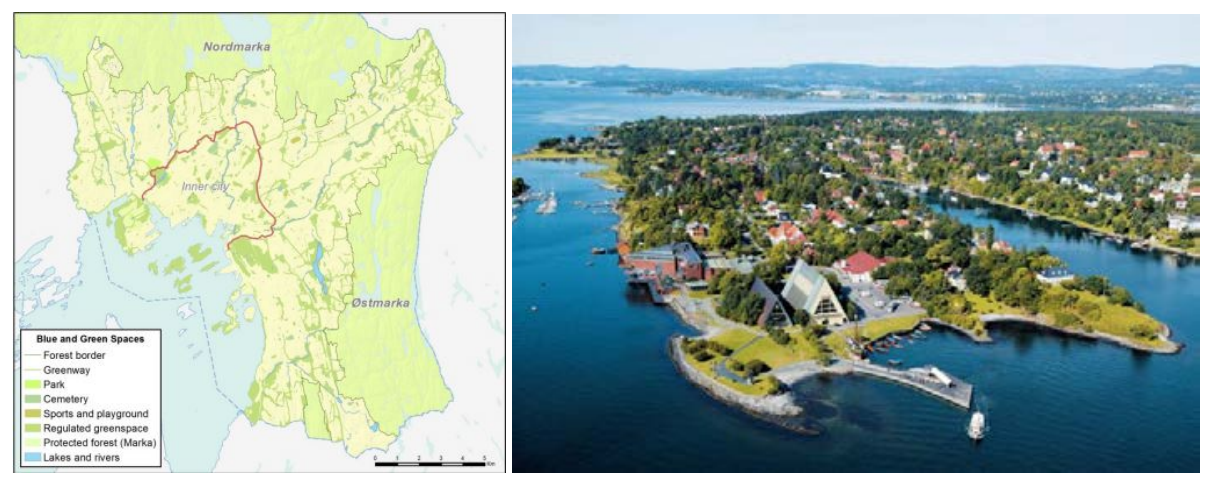

Şekil 10. Solda; Oslo kenti mavi-yeşil alanları haritası [23] Oslo'da iç içe kullanılan mavi-yeşil alanlar [24].

Oslo’nun mavi-yeşil yapısını korumak ve güçlendirmek için;

- Mavi-yeşil faktörü, yağmur suyu yönetimi ve taşkın kontrol için yeni gelişme alanlarında yeterli bitki örtüsünü sağlamak ve gerekli imar önerilerinde bulunmak,

- Ulusal korumaya tabi olmayan en önemli biyolojik çeşitlilik alanlarını imar hükümleriyle korumak,

- Kentsel Ağaçlar Stratejisi ile biyolojik çeşitliliği, halk sağlı̆̆ını ve refah duygusunu geliştirmek ve kentsel ekosistem hizmetlerine katkıda bulunmak gibi stratejiler geliştirilmiştir.

Bu stratejilere ek olarak,

- 2030’a kadar tamamen gelişmiş, yüksek standartlı yol ağı tamamlanacak,

- Yeni yeşil alanlar için alan yaratılacak,

- Ana yolların bölümlerini kapatarak yürüyüş ve bisiklete binme için fiziksel engeller kaldıracaktır.

Oslo bisiklet ağı 205 km'lik bisiklet şeridinden oluşmaktadır. Buna ek olarak, 567 km’lik rekreasyon ve bisiklet parkuru bulunmaktadır ve kış aylarında 335 km'si kayak için kullanılmaktadır. Şehrin merkezi bölgelerinde hız sınırının 30 km/s'e düşürülmesi ve Ocak 2016 itibariyle otopark ücretlerinin \%50 artırılması sonucu bisiklet kullanımı artırılmıştır. Kent, Haziran 2016'da İklim ve Enerji Stratejisini kabul ederek araba trafiğini 2019 yılına kadar \%20 azaltmayı ve 2030 yılına kadar da \%33 azaltmayı, 2020 itibariyle tüm toplu taşıma araçlarında yenilenebilir yakıt kullanılmasını ve \%16'sı bisikletle yapılan günlük seyahatlerin oranını 2025 yılına kadar \%25'e çıkarmayı hedeflemiştir [23].

\subsection{Lizbon (2020-Portekiz)}

Lizbon, 1990’larda “yeşil yapıda süreklilik” konusu üzerinde durmaya başlamıştır. 2010 yılı itibariyle Güney Avrupa İklimi'ne direnç kazanabilmek için yeşil tipolojilerde çeşitlilik ve ekosistem hizmetleri tarafindan sürekliliğin desteklendiği yeşil altyapı gelişimi gündeme gelmiştir. 2012 yılında yeşil alanları \% 20 oranında genişletebilmek için 9 yeşil koridor tanımlanmıştır ve ilk yeşil koridoru da kent dokusundaki kullanılmayan parsellerin peyzajını yeniden düzenleyerek oluşturulmuştur. Kent 2012 ana planındaki ekolojik yapı verilerine göre; 80 yıllık geçmişi olan 1123 hektar büyüklüğünde orman parkına, 50 hektardan büyük kent parklarına, 10-50 hektar büyüklüğünde kent merkezi parklarına, biyolojik çeşitlilik çayırlarına, kentsel tarım alanlarına ve en küçüğü $7500 \mathrm{~m}^{2}$ olan sayısız yeşil alana 


\section{Nevşehir Bilim ve Teknoloji Dergisi (2019), 8(Enar Özel Sayı) 1-19}

sahiptir. Lizbon halkının \%80’i bir yeşil alana en fazla 300 m mesafede yaşamaktadır. EAP Stratejisine göre, Belediye Meclis Yönetim Programı (2013-2017) ‘İnsanlar için Lizbon’ vizyonu doğrultusunda hareket etmektedir ve tüm şehir toprakları, şehir için şehir stratejisine, mevcut ve gelecekteki ihtiyaçlara göre programlanmaktadır. Kent, yeşil alanlar arasında kesintisiz erişimi sağlamaya, bisiklet kullanımına ve açık alan sporlarına verdiği önem doğrultusunda yeşil alan planlaması yapmaktadır ve bu hedefleriyle 2021 Avrupa Spor Başkenti olmaya da aday olmuştur.
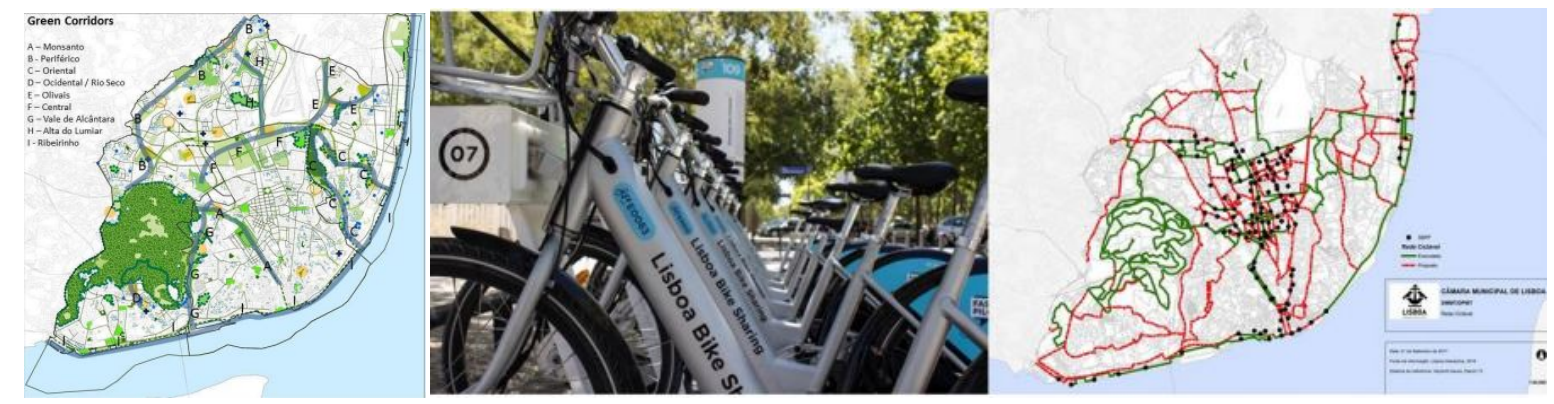

Şekil 11. Solda; Mavi çizgi ile belirtilmiş Lizbon kenti yeşil koridor bağlantısı ve yeşil altyapı haritası, sağda; paylaşımlı bisiklet kullanımı uygulaması ve kentin bisiklet ağı haritası [25].

Kentin yeşil alanların iyileştirilmesi için geliştirdiği, uyguladığı veya hedeflediği bazı proje ve politikalar;

- 2015 yılında, ekosistem kalitesini takip etmek, bağlantı sağlamak, kuşların biyolojik çeşitliliği, doğal bitki örtüsü, toprak geçirgenliği, $\mathrm{CO}_{2}$ endeksi ve ziyaretçi nüfusu gibi göstergeler de dahil olmak üzere 23 gösterge ile Biyoçeşitlilik Eylem Planı,

- Kentsel 1sı adası, taşkınlar, su kıtllğıı gibi sorunlara yeşil altyapı ile çözüm getirmeyi hedefleyen, Lizbon İklim Uyum Plan1,

- Hava kirliliği kontrolü, spor ve aktif yaşamın teşvik edilmesi, yerel gıda gibi önemli konular içeren Yeşil Dalgalanma Projesi,

- Yeşil alanların kalitesini takip etmek amacıyla, ekolojik süreklilik, yeşil tipolojiler ve yeşil alanlardaki artışlar hakkında detaylı veri içeren 2012 Master Planı (2013 ISOCARP Mükemmellik Ödülü),

- 2013 Lizbon Yaya Erişilebilirlik Planı ile yeşil koridorlar arasında bağlantının güçlendirilmesi, bisiklet ulaşımının artması, demiryolu gibi fiziksel engellerin yaya köprüleri ile aşılmasının sağlanması,

- Gıda arzını metropol ölçekte karşılamak, sosyal katılımcı ve biyoçeşitlilik içeren yeşil bir altyapı meydana getirebilmek amacıyla, 2011 yılında kentsel tarıma adanmıs 125.9 hektarlık alanın 8.2 hektarı (16 parkta 650 parsel) Kentsel Tahsis Bahçesi Programı (UAG) kapsamında halkın kullanımına açılmıştır ve böylece yerel vatandaşlık ağları kurulmuş, güvenlik ve farkındalık artmıştır,

- Yeşil çatı yüzeyini arttıranlara vergi indirimi uygulanması,

- Yağmur suyuna ve sellere karşı iklim adaptasyon çözümlerine ilişkin yeşil altyapida yeşil alanlara yönelik NBS çözümlerinin devam ettiği Drenaj Ana Planı,

- Lizbon Orman Parkı için 2016 yılında sürdürülebilir orman sertifikasyonuna ilişkin temel belgeyle sonuçlanan Sürdürülebilir Yönetim Planı gibi yasal dayanaklarla güçlendirilen gelecek planları bulunmaktadır [25].

\subsection{Avrupa Yeşil Başkenti Ödülüne Aday Kentler}

2021 yılı için; Budapeşte (Macaristan), Cagliari (İtalya), Dijon (Fransa), Lahti (Finlandiya), Lille (Fransa), Üsküp (Makedonya), Strazburg (Fransa), Tiran (Arnavutluk) ve Västerås (İsveç) kentleri aday listesinde yer almaktadır [2]. 
Nevşehir Bilim ve Teknoloji Dergisi (2019), 8(Enar Özel Sayı) 1-19

\subsection{Türkiye'den Avrupa Yeşil Başkenti Ödülüne Aday Olmuş Kentler}

Türkiye, 2014 y1lında Bursa ve Trabzon, 2015 yılında Kütahya, 2017 yılında Bursa ve İstanbul, 2020 y1lında ise Bursa şehirleri ile aday listelerinde yer almıştır [2]. Başvuruda bulunan kentler, Avrupa Komisyonu’nun belirlemiş olduğu 12 gösterge çerçevesinde yapılan, yapılmakta olan ve gelecekte yapılması planlanan çalışmalarını sunmuştur ve kentler başvuru formunda; yeşil alanların artırılması, iklim değişikliği ile mücadele, karbon ayak izinin belirlenmesi, iklim değişikliği eylem planı, entegre atık yönetimi, kentin gürültü haritasının çıkarılması, atık su arıtma tesislerinin yapılması, altyapı sisteminin yenilenmesi, katılımcı yönetim, yenilenebilir enerji kaynaklarının kullanımı, raylı sistemler ve bisiklet yollarının geliştirilmesi gibi birçok çalışma ile ön plana çıkarılmıştır. Ancak bu tür çalışmaların yapılması planlanırken başvuran kentler kişi başına düşen yeşil alan miktarları ile Avrupa standartlarına erişememektedir. Bursa kişi başı yeşil alan miktarı 2014 yılı verilerine göre $4.23 \mathrm{~m}^{2}, 2017$ y1lı verilerine göre ise 10 m²'dir [26], [27]. Trabzon kenti kişi başı yeşil alan miktarı 2013 verilerine göre 8.59 m²'dir [28]. Kütahya'da, Çevre ve Şehircilik Bakanlığı İl Çevre Durum Raporlarına göre 2011 yılında kişi başına düşen yeşil alan miktarı 12 m²'dir. İstanbul'da ise 2017 verilerine göre kişi başına düşen yeşil alan miktarı 6 m²' dir [26].

Trabzon kentinin gürültü kontrolü ve yerel ulaşım konusundaki çabaları, Bursa'nın ise atık su arıtma ve su tasarrufu çalışmaları diğer kriterlere oranla daha olumlu bulunmuştur. İki kentin başvurusunda iklim eylem planı, bisiklet, yeşil alanı arttırma, hava kirliliğini önleme, $\mathrm{CO}_{2}$ hesapları, geri dönüşümde çalışmalar ve eğitim faaliyetleri vaat olarak kalmış, gerçekleşme yüzdesi az olmuştur [3]. İstanbul'da yoğun nüfus nedeniyle oluşan konut talebini karşılayabilmek amacıyla yeşil alan miktarı oldukça düşük kalmış ve Avrupa Komisyonu tarafından incelenen birçok başlıkta istenilen seviyeler yakalanamamıştır.

\section{Tartışma ve Sonuç}

Kentlerin düzenli ve sağlıklı bir çevreye kavuşabilmesi, açık ve yeşil alanların kent içindeki dağılımına, büyüklüklerine, işlevsel ve estetik niteliklerine bağlıdır. Yeşil alanların kentin gelişmesinde etkili olması için kentlerin özellikleri dikkate alınarak sistemli bir oluşum göstermesi gerekmektedir. Türkiye’de kent planlama sürecini yönlendiren yasal mevzuat, imar planları ve imar yönetmelikleridir ve yeşil alan standartları genellikle kişi başına düşen yeşil alan miktarları şeklinde niceliksel bir yaklaşım ile belirlenmektedir. 1985 yılında çıkarılan ve halen yürürlükte olan 3194 sayılı İmar Kanunu'nda kişi başına yeşil alan miktarı 7 m² olarak belirlenmiş ve 1999 yılında yayınlanan İmar Planı Yapılması ve Değişikliklerine Ait Esaslara Dair Yönetmelik’le kişi başına yeşil alan miktarı $10 \mathrm{~m}^{2}$ 'ye çıkarılmıştır. Bu yaklaşım gerekli olabilir fakat yeterli değildir. Avrupa Yeşil Başkenti seçilen kentlerin kişi başı yeşil alan miktarlarını incelediğimizde; Stockholm $87.5 \mathrm{~m}^{2}$, Hamburg $17 \mathrm{~m}^{2}$, Vitoria-Gasteiz $46.12 \mathrm{~m}^{2}$, Nantes $57 \mathrm{~m}^{2}$, Kopenhag 42.4m², Ljubljana $66 \mathrm{~m}^{2}$ ve Nijmegen $40 \mathrm{~m}^{2}$ olduğu bilinmektedir. Dünya Sağlık Örgütü (WHO), yeşil alanların nüfusa bakılmaksızın $9 \mathrm{~m}^{2}$ olması gerektiğini ancak ideal rakamları kişi başına 10-15m² olarak uygulanması gerektiğini ifade etmiştir. Türkiye'de ise kişi başı $10 \mathrm{~m}^{2}$ yeşil alan ile Bursa, $8.59 \mathrm{~m}^{2}$ ile Trabzon, $12 \mathrm{~m}^{2}$ ile Kütahya ve $6 \mathrm{~m}^{2}$ ile İstanbul, Avrupa kentlerinin sahip olduğu kişi başı yeşil alan miktarlarının çok altında kalmaktadır. Ayrıca Türkiye'de birçok kent merkezi, kanunlarda yer alan kişi başına $10 \mathrm{~m}^{2}$ yeşil alan bırakılması zorunluluğuna plan üzerinde uymasına rağmen, planda alınan kararları uygulamaya geçirememekte ve kamusal yeşil alanlar bakımından oldukça yetesiz kalmaktadır.

Türkiye'de mevcut imar mevzuatında bir yeşil alan sistemi oluşturulmasına ilişkin öngörü bulunmaması; makro ölçekten mikro ölçeğe giden bir yeşil alan planlama stratejisinin oluşturulamamış olması; parçacıl planlarla oluşturulan ve değiştirilen yeşil alan kararları, bugün kentlerimizin yeterli yeşil alandan yoksun oluşunun en önemli nedenleri arasındadir[26], [29]. 
Nevşehir Bilim ve Teknoloji Dergisi (2019), 8(Enar Özel Sayı) 1-19

Avrupa Yeşil Başkenti ödülü alan kentlerin detaylı incelenmesi sonucunda her bir kentin yeşil alan ağ oluşturma veya var olanı koruyup geliştirmeye yönelik çok sayıda politikalar uyguladığı belirlenmiştir. Türkiye'de de imar planında öngörülen yeşil alanlar ile kente çok sayıda park kazandırmak politikası yerine ödüllü kentlerde gördüğümüz gibi en az $5000 \mathrm{~m}^{2}$ büyüklüğünde fonksiyonel niteliklere sahip parklardan oluşan sistemli bir yeşil alan ağ1 oluşturulmasına olanak sağlayan yaklaşımlar benimsenmelidir. Yeşil alanların kent içindeki işlevlerini yerine getirebilmeleri için nitelik ve nicelik olarak yeterli olmasının yanı sıra ulaşılabilir olmaları da önemlidir. Avrupa Komisyonu Kentsel Denetim raporunda da kentsel yeşil alanlar için 15 dakika yürüme mesafesinde olma kriteri getirilmekle birlikte, yeşil alanlara bu mesafede yaşayan nüfusun toplam kent nüfusuna oranı değerlendirmeye alınmakta ve bu oran Avrupa kentleri için \%64,8 olarak verilmektedir [30]. Avrupa Yeşil Başkenti seçilen kentlerin tamamında halkın \%80-100'ü bir yeşil alana maksimum 300 m mesafede yaşadığı gerçeğini dikkate alarak Türkiye'de de erişilebilirlik konusuna dikkat çekmek gerekmektedir. Aynı şekilde erişilebilirlik, araç kullanımını kısıtlayarak hava kalitesini artırma ve aktif bir kent yaşamı sunma hedefleri olan Avrupa kentleri gibi Türkiye'de de bisiklet kullanımını teşvik eden ve bisiklet yol ağı oluşturarak halka olanak sunan yaklaşımlar benimsenmelidir.

Trabzon ve Bursa'nın kısa listeye kalan Bristol’unki gibi iklim değişikliği programlarına, Kopenhag gibi organik gıda üretimi ve eko-inovasyon uygulamalarına ihtiyacı vardır. Bir zamanlar "yeşil” sıfatıyla anılan bu iki kentin yeşil ova ve vadileri yapılaşma yüzünden tahrip olmuştur. Trabzon ve Bursa'da kentsel yayılma yerine kompakt bir kent örüntüsü benimsenmeli, kent çeperi tarımda organik gıda üretilmeli, belediyeleri öncelikle kendi yapılarında çevreci tedbirler almalı ve eğitim faaliyetlerini arttırmalıdır. Otoyollar yeşil tampon bölgelerle ayrılmalı, kent merkezlerinde araç girişi kısıtlanmalı, bisiklet yol ağı geliştirilmeli ve altyapıda ekolojik çözümlere gidilmelidir [3]. Yoğun kentleşme oranına sahip olan İstanbul'da da Kopenhag ve Nijmegan'da olduğu gibi yeşil çatı uygulamaları ile yeşil yüzeyler artırılmalıdır. Bu kapsamda Lizbon'da olduğu gibi yeşil çatı yüzeyini artıranlara vergi indirimi gibi uygulamalarla halk teşvik edilmeli, yoğun çalışma hayatı içerisinde olan kentte halkın yeşil alanlardan Vitoria-Gasteiz'de olduğu gibi kent bahçeciliği şeklinde faydalanmasına olanak sağlanmalıdır. Kentsel yayılma kontrol altına alınmalı ve kent yaşamının kalitesini arttırmaya yönelik politika ve uygulamalar hayata geçirilmelidir. Bunlara ek olarak Türkiye’deki tüm kentlerde, yerel sahipleniş konusuna odaklanılmalı, Kopenhag'da olduğu gibi parklar halkın ortak bahçesi bilinci içerisinde değerlendirilmeli, Lizbon ve Nijmegen'de görüldüğü gibi yerel yönetimler yeşil alanların bakım, kullanım ve gelişimi gibi konularda halk ile iş birliği içerisinde olmalıdır. Tüm bunlara ek olarak yeşil vizyonla iddialı hedeflerin konması ve parçacıl yaklaşımlardan ziyade mavi ve yeşil alanlar uyum ve birliktelik içerisinde düşünülmeli, kent içi ve çevresindeki alanları birbirine bağlayan nitelikte bisiklet yolları ile desteklenen yeşil-mavi koridorlar planlanmalıdır. Yeşil alanların ekolojik olarak bağlantılı olması, gerek kent kullanıcıları ve gerekse kentsel alanda yaşayan diğer canlılar için de hareket olanağı sağlamaktadır. Kentsel konut alanlarının yeşil alanlara uzaklığı konusu özellikle üzerinde durulan konulardan biri olarak dikkat çekmektedir ve en az kişi başına düşen yeşil alan miktarı kadar, en yakın yeşil alana uzaklık da bir kriter olarak değerlendirilmiştir.

Birleşmiş Milletlerin 2018 yılı Dünya Şehirleşme Raporlarına göre dünya nüfusunun \%55.3’ü kentlerde yaşamaktadır. Dünya genelinde kentlerde yaşayan nüfus oranı 1950’li yıllarda \%30 civarında iken, 2030 yılına kadar \% 60'a ulaşması beklenmektedir. Hızla artmakta olan kentleşme eğilimi nedeniyle, her kentin mevcut durumunu değerlendirmesi ve geleceğe yönelik uygulanabilir projeler ve planlar üretmesi zorunluluktur. 


\section{Kaynaklar}

[1] Cömertler S., 2017. 2010-2018 Avrupa Yeşil Başkentleri, Uşak Üniversitesi Fen ve Doğa Bilimleri Dergisi, 41-56.

[2] European Commission, 2019. Green Cities Fit For Life, Evaluating Process. http://ec.europa.eu/environment/europeangreencapital/applying-for-the-award/evaluation-process/.

[3] Yalçıner, Ö., 2012. Avrupa Yeşil Başkent Unvanı Üzerine, Mimarlık Dergisi, sf.367.

[4] Diler G., 2012 Avrupa Birliği’nin İlk Yeşil Başkenti Stockholm, EKOYAPI Dergisi, 9, 90-94.

[5] Metin, S., 2012. Avrupa’nın Üçüncü Yeşil Başkenti, Vitoria - Gasteiz, EKOYAPI Dergisi (10) 120-125.

[6] Şahin, H., 2012. Avrupa'nın Dördüncü Yeşil Başkenti: Nantes, EKOYAPI Dergisi, 11, 92-96.

[7] Yener, H., 2012. Avrupa'nın Beşinci Yeşil Başkenti: Kopenhag, EKOYAPI Dergisi, 12, 84-86.

[8] European Commission, 2010a; Stockholm European Green Capital 2010, European Union Publications, Belgium.http://ec.europa.eu/environment/europeangreencapital/

[9] Xıu, N., Ignatıeva, M., Bosch, C.K., 2016. The Challenges of Planning and Designing Urban Green Networks in Scandinavian and Chinese Cities, Journal of Architecture and Urbanism, 2016, 40(3), 163-176.

[10]European Commission, 2008; The City of Stockholm, Stockholm Application for European Green Capital Award Revised Version. http://ec.europa.eu/environment/europeangreencapital.

[11]Guzman C.B., 2017; Suburban Wetlandia. ,Princeton Architectural Press, New York, pg 489. https://enviropaul.wordpress.com/2018/02/01/the-green-network-of-hamburg/

[12]European Commission, 2011; Hamburg European Green Capital 2011, European Union Publications, Belgium,http://ec.europa.eu/environment/europeangreencapital/wp-

[13]European Commission, 2009; The City of Hamburg, Hamburg Application for European Green Capital Award, http://ec.europa.eu/environment/europeangreencapital/winning-cities/

[14]European Commission, 2012a; The City of Vitoria - Gasteiz, Vitoria - Gasteiz 2012 European Green Capital, Final Report, http://ec.europa.eu/environment/europeangreencapital/wp-content/uploads/2011/04/VG-GreenConclusiones.pdf

[15]European Commission, 2010b; The City of Vitoria-Gasteiz, Vitoria-Gasteiz Application for European Green Capital Award, http://ec.europa.eu/environment/europeangreencapital/

[16] European Commission, 2010c; The City of Nantes, Nantes Application for European Green Capital Award, http://ec.europa.eu/environment/europeangreencapital/winning-cities/2013-nantes/nantes-application/

[17]European Commission, 2012b; The City of Copenhagen, Copenhagen Application for European Green Capital Award, http://ec.europa.eu/environment/europeangreencapital/winning-cities/2014-copenhagen/copenhagenapplication/

[18]European Commission, 2013; The City of Bristol, Bristol Application for European Green Capital Award, http://ec.europa.eu/environment/europeangreencapital/winning-cities/2015-bristol/bristol-application/

[19]European Commission, 2015a; The City of Ljubljana, Ljubljana Application for European Green Capital Award, $\quad$ http://ec.europa.eu/environment/europeangreencapital/winning-cities/2016-ljubljana/ljubljana-2016application/

[20]European Commission, 2015b; The City of Essen, Essen Application for European Green Capital Award, http://ec.europa.eu/environment/europeangreencapital/winning-cities/2017-essen/essen-2017-application/ 
Nevşehir Bilim ve Teknoloji Dergisi (2019), 8(Enar Özel Sayı) 1-19

[21]European Commission, 2018a; Nijmegen European Green Capital 2010, European Union Publications, Belgium. http://ec.europa.eu/environment/europeangreencapital/

[22] European Commission, 2016; The City of Nijmegen, Nijmegen Application for European Green Capital Award, http://ec.europa.eu/environment/europeangreencapital/winning-cities/2018-nijmegen/nijmegen-2018application/

[23]European Commission, 2017; The City of Oslo, Oslo Application for European Green Capital Award, http://ec.europa.eu/environment/europeangreencapital/winning-cities/2019-oslo/oslo-2019-application/

[24]URL-1 : http://44mpa.pl/nijmegens-passionate-vision-wins-green-capital-2018/?lang=en

[25] European Commission, 2018b; The City of Lizbon, Lizbon Application for European Green Capital Award, http://ec.europa.eu/environment/europeangreencapital/winning-cities/2020-lisbon/15210-2/

[26]Benek S., Şahap A., 2017. Şanlıurfa Şehrinde Coğrafi Bilgi Sistemleri (CBS) ve Uzaktan Algilama(UA) Kullanılarak Yeşil Alanların Yeterliliğinin Belirlenmesi, Marmara Coğrafya Dergisi, 36, 304-314.

[27]Fidan A.N., 2014; 2017 Avrupa Yeşil Başkenti Yarışma Başvuru Süreci \& Bursa, Yeni Şehirler Zirvesi, 11-12 Aralık 2014-Bursa, https://docplayer.biz.tr/645053-2017-avrupa-yesil-baskenti-yarismasi-basvuru-surecibursa.html

[28]URL-2:https://www.iha.com.tr/haber-trabzonda-kisi-basi-dusen-yesil-alan-859-metrekare-308501/

[29] Manavoğlu E., Ortaçeşme V., 2007; Konyaaltı Kentsel Alanında Bir Yeşil Alan Sistem Önerisi Geliştirilmesi, Akdeniz Üniversitesi Ziraat Fakültesi Dergisi, 2007, 20(2), 261-271.

[30]Doygun H, İlter A., 2007; Kahramanmaraş Kentinde Mevcut ve Öngörülen Aktif Yeşil Alan Yeterliliğinin İncelenmesi. Ekoloji 17, 65, 21-27.

\section{Extended Abstract}

\section{Introduction}

Acording to the 2018 World Urbanization Report of the United Nations, 55.3\% of the world's population lives in urban areas. The proportion of the population living in cities across the world is expected to reach $60 \%$ by 2030 while it is around $30 \%$ in the 1950 s. Due to the rapidly increasing urbanization trend, concepts such as the presence, size and effective use of open and green areas, which are vital in urban areas, have gained importance. Open and green areas; linking between urban and rural areas, providing opportunities for recreational activities, reducing the impact of environmental pollutants, regulating microclimate and surface flow, improving urban aesthetics, creating a suitable living space for plant and wildlife species, improving people's living conditions and performing many other functions important urban biotopes.

The aim of this study is to examine the policies of open and green areas through Green Capital concept and European Green Capitals. The concept of green capital which emphasizes the quality of urban life and draws attention with its environmentalist approach and in this context the international recognition of green capital award are discussed for the open and green areas which have much importance in the normal course of life. This award winning of cities, far enough not recognized in Turkey, and it was observed that a small number of research in Turkey on this issue

\section{Method}

Stolkholm, Hamburg, Vitoria-Gasteiz, Nantes, Kopenhag, Bristol, Ljubljana, Essen, Nijmegen, Oslo and Lizbon cities which were selected as European Green Capital between 2010-2020 were examined. In the study, literature and document scanning method has been used and the subject is evaluated within the frame of 12 indicators which are required to have the title of Green Capital. In the Green Capital prepared application reports, it is focused on the sections titled 'Local Transport and Green Urban Areas Incorporating Sustainable Land Use'. Turkey’s basic policies on green areas as a result of the examinations were evaluated. In addition, applications for open and green areas of cities nominated for the award green capital from Turkey were discussed. 


\section{Nevşehir Bilim ve Teknoloji Dergisi (2019), 8(Enar Özel Sayı) 1-19}

\section{Results and Discussion}

Green standards in Turkey are generally determined by a quantitative approach as the amount of green space per capita. The World Health Organization (WHO) stated that the amount of green area per capita should be $9 \mathrm{~m}^{2}$ regardless of the population, but the ideal figures should be applied as $10-15 \mathrm{~m}^{2}$ per capita. Turkey remains far below the amount of green space per capita owned by European cities.

As a result of a detailed examination of the cities that have been awarded the European Green Capital, each city has implemented a number of policies aimed at creating a green area network or protecting and developing an existing one. A systematic approach that allows the creation of green area network in Turkey should be adopted should draw attention to accessibility issues, encouraging the use of bicycles and public facilities offering approaches to creating a network of bicycle paths should be adopted. In addition, ambitious goals need to be set with the green vision, and blue and green spaces should be considered in harmony and unity rather than fragmentary approaches.

While the proportion of the population living in cities around the world is around $30 \%$ in the 1950 s, it is expected to reach $60 \%$ by 2030 . Due to the rapidly increasing urbanization tendency, each city should evaluate its current situation and produce feasible projects and plans for the future. 